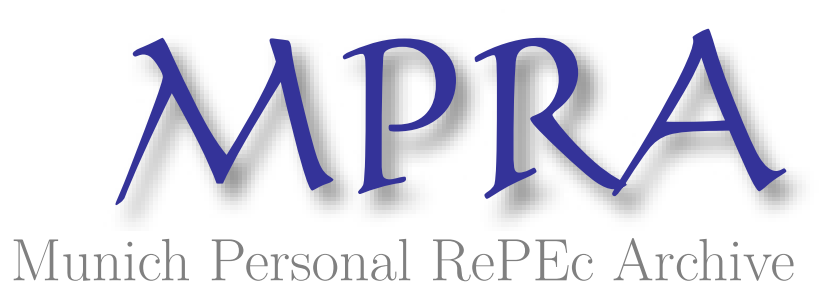

\title{
Social Interaction Effects and Connection to Electricity: Experimental Evidence from Rural Ethiopia
}

Bernard, Tanguy and Torero, Maximo

IFPRI, IFPRI

September 2014

Online at https://mpra.ub.uni-muenchen.de/61303/

MPRA Paper No. 61303, posted 14 Jan 2015 13:29 UTC 
Social Interaction Effects and Connection to Electricity:

Experimental Evidence from Rural Ethiopia

Tanguy Bernard

International Food Policy Research Institute

Lot no. 2-Titre 3396

BP 24063 Dakar, Almadies

Dakar, Sénégal

t.bernard@cgiar.org

$+221774925488$

Maximo Torero

International Food Policy Research Institute

2033 K St. NW

Washington, DC, USA

m.torero@,cgiar.org

$+1202-862-5600$

Acknowledgments

We are grateful to the Ethiopian Electric Power Corporation - in particular Amenu Teffera-for its involvement in piloting this experiment, and to the Ethiopian Economic Association for help with data collection. Maribel Elias and Sara Gustafson provided significant research assistance. Useful comments and suggestions were provided by Ruth Vargas-Hill, David Spielman, Alemayehu Seyoum Taffesse, Pippa Chenevix Trench, Gian Nicola Francesconi, Jenny Aker. 


\begin{abstract}
This paper assesses the importance of social interactions in determining an individual's choice to connect to an electrical grid, using an original dataset on a new rural electrification program in Ethiopia. Combining GPS information with random allocation of discount vouchers for connection to the grid, we show that neighbors' connection behaviors have large effects on a household's connection decision. This effect is also shown to decrease by distance: no peer effect is found for neighbors living farther than 100 meters away. Evidence also suggests that expectation interactions (through social learning of the benefits of electricity) or constraint interactions (through direct externalities of one's connection on others' wellbeing) are unlikely to fully account for these effects, and that preference interactions (through a 'keeping up with neighbors' type of mechanism) appear to be a plausible explanation. We discuss implications for further research and the design of development interventions.
\end{abstract}

Keywords: Ethiopia, Rural Electrification, Social Interactions

JEL codes: O33, O12, C93 


\section{Motivation}

Social interaction effects concern to the extent to which an individual's decision to adopt a particular behavior is in part driven by the behavior of (relevant) others, above and beyond market-driven influences. The magnitude and underlying mechanisms of such effects bear significant consequences for public policies. Depending on their size, social interaction effects may contribute to high or low adoption equilibrium of particular commodities, technologies, or behavior. Depending on their underlying mechanisms, they may necessitate different policies to reach certain adoption equilibrium.

Social interaction effects are likely to be present even in poor settings. It is striking, for instance, that mobile phone penetration into countries such as Kenya, Niger, or Haiti has far exceeded expectations (Aker and Mbiti 2010), and some authors point to the importance of peer influence on individuals' decisions to purchase a cell phone (e.g. Kreutzer 2009, Makgosa and Mohube 2007, Yang, He and Lee 2007, Aboagye 2013). In turn, and following Manski (2000), these effects may result from constraint interactions, wherein others' cell phone ownership may affect one's own capacity to make phone calls; expectation interactions, wherein seeing others using their cell phone allows one to learn more about the benefits of having one; or preference interactions, wherein cell phone ownership carries some social value that may (partly) drive one's adoption. Thus, depending on the underlying mechanism, policies such as subsidies, information campaigns, or social marketing may lead to very different adoption equilibriums.

This paper tests for the presence of social interaction effects on households' decision to connect to a newly installed electrical grid in rural Ethiopia and attempts to identify the underlying factors at work. At a time when rural electrification is being promoted throughout Sub-Saharan Africa, understanding households' connection decisions has led to significant debates (see Bernard (2010) for a review). The study's setting is arguably ideal, as no electricity was available in the surveyed communities when we collected baseline data and electrical lines were installed in the community shortly thereafter. Connection to the grid is expensive, however, and only a proportion of the sampled households chose to connect to the grid over the following 12 months.

Identifying social interaction effects requires the neutralization of other factors that may also produce homogenous behavior among peers (Manski, 1993). For instance, one may observe similar connection rates among neighbors because they face similar connection prices or because households with similar economic means tend to live in the same locations. Thus, our study relies on the random allocation of non-transferable vouchers that provided a discount on connection to the grid, as well as household-level GPS locations. Connection price being an important driver of a household's choice to connect, the vouchers provide an exogenous variation in the number of connected neighbors within a particular distance radius, allowing us to identify social multipliers effects (see Kremer and Miguel (2007), Dupas (2010), and Devoto et al. (2011) for similar approaches).

Our results show that neighbors' connection behavior has large effects on a household's connection decision. This effect also decreases by distance, with no peer effect found for 
neighbors living farther than 100 meters away, leading to sub-village clusters of high/low density of electrified households.

Our data does not allow us to directly test for the mechanisms underlying the identified social interaction effect; however, indirect evidence suggests that expectations interactions, wherein households learn from connected neighbors about the benefits of electricity, are not the main driver. In fact, we find even higher social interaction effects in the subsample of households with the highest knowledge of electricity at baseline. Further, there is no evidence of electricity's benefits in the short run of the study, in terms of either productive use or changes in time allocation - such as study time or time necessary to collect fuel wood. There is also no evidence of a reduction in energy bills given the number of available and more affordable (though lowerquality) substitutes for electrical lights. Finally, given the program design, it is unlikely that households could learn from others 'how' to obtain connection. Thus, it appears unlikely that individuals' connection decisions are being driven by increased knowledge about the benefits of electricity.

The study's field setting also allows for only limited constraint interactions, wherein households would benefit from or be constrained by others' connection decisions. The connection price is fixed by the electrical utility company and cannot be reduced by a higher number of neighbors simultaneously connecting to the grid. In addition, the main electrical implements used are lightbulbs, which are readily available and which price is unlikely to be affected by local demand. Finally, one could argue that enhanced lighting in electrified households generates negative externalities on non-connected ones, for instance through more frequent visits to the former at the expense of the latter. Yet no such effect is found in households' time allocated to entertaining visitors.

With limited expectation and constraint interactions (at least in the short time-span of the study), preference interactions offer a reasonable explanation for the social interaction effect observed. Households' electrification status is readily observable by all neighbors through the drop-down wire that connects a house to the nearest electrical pole, directly enabling social comparisons. And while our data does not allow us to directly test for such effects, a number of case studies in various other contexts suggest that electrification often carries a social status dimension in rural communities. Accordingly, individuals are often willing to invest significant resources in order to keep up with neighbors' social status.

The rest of the paper proceeds as follows. Section 2 provides a short description of the institutional setting of the study, the study design, and the experimental integrity of the data collected. In Section 3, we develop the empirical strategy used to identify social interaction effects in connection behavior, which is applied in Section 4. Section 5 further assesses the respective plausibility of underlying drivers for the observed social interaction effect, namely expectation interactions, constraint interactions, and preference interactions. Section 6 concludes and discusses further research needs and potential policy implications. 


\section{Study Setting}

With less than one percent of households having access to electricity in the early 2000s, Ethiopia has one of the lowest rural electrification rates in the world (Estache and Fay, 2007). Since 2005, however, the Universal Energy Access Program (UEAP) has sought to dramatically change the scenery, starting with new electricity supply to 1,000 non-electrified villages. Within each selected village, households were responsible for the costs of connecting to the main electrical line; these expenses included the cost of installing a drop-down line from the nearest pole and the cost of installing a meter. Overall, connection prices ranged from around 300-450 Ethiopian birr (ETB) among connected households in our sample, ${ }^{1}$ depending on a house's distance to the nearest pole. For comparison purposes, per capita monthly food expenditure was evaluated at less than 150 ETB during this time period.

As part of a broader effort to measure and understand barriers to electrical connectivity, the present study relies on an experiment in which discount vouchers of 10 and 20 percent were randomly allocated to households in eight selected village communities in Southern Ethiopia that were soon to be electrified under the UEAP program. In each village, the allocation of vouchers was done at random through a clear and transparent public lottery based on administrative village listings. The voucher design itself was rather complex, involving watermarks, official stamps, and unique serial numbers to reduce the risk of falsification. In addition, clear instructions regarding the non-transferability of the vouchers were given both in writing and orally, and each recipient's name, national identification number, and address were written on the voucher at the time of distribution. ${ }^{2}$

In each village, 90 households were randomly selected for a survey at the time of the lottery; some of these households were then further selected to receive a voucher. Of the households selected, however, we later found that a number lived too far from the upcoming grid to be considered for electrification. Overall, our effective sample varies from 68-89 households per village, which corresponds to roughly 10 percent of the average village population and is representative of all households which were effectively given the choice to connect to the newly installed grid. Within these households, an average 65 percent were provided with a discount voucher. A follow-up survey was conducted 12 months after baseline.

For each household, survey questionnaires included the standard set of demographic and incomeconsumption expenditure modules, along with specific modules dedicated to energy usage. We also collected the GPS location of each household's compound to further assess the distance to the nearest electrical pole and hence proxy connection prices.

As shown in the first panel of Table 1, the random selection of households to receive a voucher was fairly well executed, such that no differences in the basic characteristics of voucher recipients and non-recipients were found at baseline. Further, we find no significant differences between voucher recipients and non-recipients in terms of households' initial knowledge of the

\footnotetext{
${ }^{1}$ Roughly equivalent at the time of our baseline survey to US\$30-45.

${ }^{2}$ The lottery itself was conducted by the Ethiopian Electric Power Corporation (EEPCo) with which the study was implemented. See Bernard and Torero (2011) for further description of the experiment.
} 
benefits of electricity, ${ }^{3}$ in baseline time allocation, or in mean distance to the nearest electrical pole. Finally, the spatial distribution of vouchers was not geographically clustered - a point of importance for the following analyses - as shown by the distribution's independence from the density of housing around an individual's house.

\section{Identification of Social Interaction Effects}

To empirically identify social interaction effects, it is useful to first build on the general insights of existing models. A valuable starting point is the approach of Granovetter (1978), who proposes a threshold model in which an individual's decision to undertake a particular action depends on the number of others who have decided to undertake that same action in previous periods. In this model, each individual is defined by a different threshold level.

In this model, social interaction effects will lead to a type of bandwagon dynamic under two conditions. The trend must first be started by individuals who are willing to engage in a particular behavior without knowing either others' past actions or others' eventual future decisions. In an analogy with the treatment effect literature, these low-threshold individuals may be referred to as the always takers. The bandwagon dynamic then requires that the distribution of thresholds among compliers (those who need to observe others' behavior before deciding on their own) must be continuous enough so that each additional individual adopting the behavior will trigger the decision of one or more additional individuals to do so. The bandwagon will effectively stop either when large gaps exist within the threshold distribution or when the only remaining individuals are those who would never engage in the said behavior, whatever others' choices (the never-takers).

Importantly, however, Granovetter (1978) argues that not all individuals exert the same influence over others. For instance, the social influence of a friend may be larger than that of a stranger; similarly, it may be easier to derive information from observing a neighbor's behavior than from observing the behavior of someone farther away geographically. This idea is also discussed in Brock and Durlauf (2001), who distinguish between global interactions, in which the same weight is given to all population members, and local interactions, in which individuals within one's geographic or social vicinity are given greater weight (see also Moffitt, 2001). In a somewhat related vein, Akerlof (1997) uses a gravity model to describe how individuals may trade - that is, in a social interaction perspective - more with individuals who are 'close by' with respect to their lifestyle. The distribution of these interaction weights may then produce subcultures, whereby clusters of particular behavior are observed within a given community. In places with scattered populations, social interactions effects will be weak and no such bandwagon dynamic will be observed.

Applied to the case of rural electrification, two separate propositions can be extracted from these general models. First, bandwagon dynamics will be triggered by those individuals for whom the intrinsic value of electricity is a sufficient incentive to connect to the electrical grid, whatever others' behavior. Second, social interaction effects may depend on one's ability to observe others' connection behavior or to be affected by their behavior, which may diminish with the

\footnotetext{
${ }^{3}$ This variable is further described in Section 5.1.
} 
geographic distance between households. Thus, for a given threshold, a household may adopt a different connection behavior based on the distribution of always takers, never takers, and compliers within that household's vicinity. This effect, in turn, may lead to the existence of subcommunity clusters of high or low connection rates. Finally, it should be noted that at this stage, expectation interactions, constraint interactions, and preference interactions are all equally likely to be the underlying driver of the bandwagon dynamic.

For illustrative purposes, and as preliminary evidence of the presence of social interaction effects in electrical connection decisions, Figure 1 maps households' locations, along with their connection status and their distance to the electrical line, in one of the eight villages under study. The picture reveals a number of clusters of connected (black) and unconnected (white) households. These clusters do not a priori bear a clear relationship to households' distance to the electrical line, which, as noted earlier, significantly affects connection prices. Finally, these clusters mostly correspond to households that are located less than 200 meters from one another.

Several additional factors may explain this connection pattern, apart from genuine social interaction effects (cf Manski, 1993). First, the composition of physical clusters is endogenous: individuals in these clusters may behave in common ways because they share similar attributes that drove both their location choice in the past as well as their current decision to connect or not connect to the electrical grid. Second, households within clusters are exposed to similar contexts and contextual changes and may react to them accordingly. Finally, cluster members may genuinely influence one another through social interactions, either through their exogenous characteristics - the so-called exogenous effect - or through their actual connection behaviorendogenous effects. As discussed elsewhere (Manski, 1993, 2000; Moffitt, 2001; Scheinkman, 2008; and others), only endogenous effects are prone to generate the kind of social multiplier that may explain large differences across clusters when there are no significant differences in underlying fundamentals.

The so-called reflection problem, formalized in Manski (1993), poses yet another challenge to the empirical identification of endogenous social interaction effects. Since group behavior is simultaneously influenced by individual behavior, simple linear-in-means models, whereby an individual's action is regressed on the prevalence of this action within the group, cannot distinguish between exogenous and endogenous social interaction effects. Non-experimental solutions have been proposed, including the addition of further exclusion restrictions to the model and the reliance on nonlinearities, which allow for multiple equilibriums (for example, Brock and Durlauf, 2001; Blume and Durlauf, 2005). Other potential solutions rely on models in which one's behavior varies with lagged group outcomes under the assumption that "nonsocial forces act contemporaneously but social forces act on the individual with a lag" (Manski, 1993, p540). Finally, experimental settings provide promising identification avenues, exogenously affecting either group membership (for example, Sacerdote, 2001; Katz, Kling, and Liebman, 2001 ) or the behavior of some individuals within existing groups (for example, Duflo and Saez, 2003).

Our approach is akin to the latter, whereby randomly selected households within village communities were provided discount vouchers as an extra incentive to connect to the electrical grid. Given the importance of connection cost to households' connection decision, voucher 
recipients are more likely to have connected over the course of the study than their fellow villagers who did not win the lottery. The randomness of the voucher allocation among an individual's peers ensures independence from that individual's observable and unobservable characteristics. Our study is thus a partial population experiment, whereby "there exists an exogenous variable that affects one individual directly but affects the other only through the endogenous social interaction" (Moffit 2001, p. 59).

An additional issue relates to the definition of groups themselves. As reminded by Manski (1993), researchers must first know how individuals form reference groups and perceive reference group outcomes before they can infer social interactions. In this paper, we take a rather exploratory approach to the definition of a reference group: we investigate the extent to which reference groups evolve with distance. Our data allows us to identify the level of social interaction effects for various definitions of a geographical neighborhood by changing the distance radius that is considered to select one's neighbors (see Kremer and Miguel, 2007; Dupas, 2010; Devoto et al., 2011 for similar approaches). A caveat, however, is that group membership itself does not change quickly relative to the influence of social interactions (Moffit, 2001). In our case, this means that housing location will not change as a result of group-level connection behavior. The time span of our study is relatively short, however, and it is highly unlikely that housing location changed over the course of the 12 month study. A second caveat is that one's reference group may be only partially correlated with the physical distribution of one's neighbors, such that our measure is at best a proxy.

Adapting Manski's (1993) setting to our purpose, our estimation can be described as

$$
c_{i}=\alpha+\beta \cdot \bar{c}_{-i \in d i}+\delta \cdot h_{d i}+z_{i}^{\prime} \tau+u_{i}
$$

where $c$ is a binary outcome indicating whether a household has connected to the grid over the 12 months of the study; $d i$ characterizes one's reference group, which in this case is a distance radius around one's house; $\bar{c}_{-i \in d i}$ measures the number of neighbors connected to the grid within $d$ meters from $i$ 's house; $(z, u)$ are observable and non-observable attributes of the household that directly affect $c$ (such as wealth, connection price, and preferences); and $h$ controls for the population density within the radius. In fact, one may argue that the distribution of connected households somewhat follows the geographic distribution of households in general, which could lead to the incorrect interpretation that the coefficients reveal social interaction effects.

The parameter $\beta$ is meant to capture endogenous social interactions-namely, the extent to which an individual's connection behavior is influenced by the connection decision of other households living within a $d$-meter geographical radius. As discussed earlier, $\beta$ may well capture a variety of other reasons as to why neighboring households tend to behave in similar ways, resulting in a potentially biased estimate of $\beta$.

The study design, however, allows us to circumvent this issue by using the exogenous number of voucher recipients within the vicinity as a valid instrument for the number of connected households. Equations (2), (3) and (4) summarize our empirical strategy.

$$
c_{i}=\alpha^{\prime}+\beta^{\prime} \cdot \bar{v}_{-i \in d i}+\delta^{\prime} \cdot h_{d i}+z_{i}^{\prime} \tau^{\prime}+u_{i}
$$




$$
\begin{aligned}
& \bar{c}_{-i \in d i}=a+b \cdot \bar{v}_{-i \in d i}+c . h_{d i}+z_{i}{ }^{\prime} d+\mu_{i}, \\
& c_{i}=\alpha^{\prime \prime}+\beta^{\prime \prime} . \hat{c}_{-i \in d i}+\delta^{\prime \prime} . h_{d i}+z_{i}{ }^{\prime} \tau^{\prime \prime}+u_{i}
\end{aligned}
$$

Accordingly, $\beta^{\prime}$ in Equation (2) captures the reduced form coefficient of the experiment, while Equation (3) describes the first stage of the Two-Stage Least Square estimate of the social interaction effect described in Equation (4), in which $\hat{c}_{-i \in d i}$ is the predicted value of $\bar{c}_{-i \in d i}$ obtained from Equation (3).

\section{Results}

Results of the reduced form, the first stage, and the second stage estimations described in Equations (2), (3), and (4) are reported in Tables 2, 3, and 4, respectively. For each, we use GPS coordinates to report estimates when considering distance radiuses of 10,30,50, and up to 500 meters. Thus, within each panel of each table, each column relates to an independent estimate corresponding to a particular size of radius. For comparison and robustness purposes, Panel A in each table reports the estimated results without any controls, while population density in the considered radius is added in Panel B and further household-level characteristics are added in Panel C.

Table 2 presents the results of the reduced form estimates of Equation 2. Accordingly, the number of voucher recipients within one's vicinity has a rather strong effect on a household's decision to connect when we consider small radiuses; this effect eventually disappears after 200 meters. According to Panel C, each additional household that received a voucher within a 30 meter radius increases the probability that an individual will connect by close to 2 percentage points. With an average connection rate of 41 percent, this result suggests a close to $4 \%$ increase in the connection rate for each additional connected neighbor within a 30 meter radius. For 100 meters or more, the influence is reduced to 0.3 percentage points before it becomes statistically insignificant.

The results are rather consistent across all three panels. Comparing Panel A and Panel B, we find that controlling for population density does have a downward effect on the estimate, although the general magnitude remains unchanged. Results from Panel $\mathrm{C}$ also confirm the existence and size of the social interaction effect. The results overall confirm important determinants of households' connection decisions, as documented in existing literature on rural electrification in Sub-Saharan Africa. For instance, Heltberg (2003) showed that in Ghana and South Africa, fewer than 5 percent of rural households in the lowest revenue quintile connected to electricity, while this rate reached between $25-50$ percent for the highest quintile. Our results are very much in line with these findings, showing that one's distance to the nearest electrical pole is negatively related to one's connection decision, whereas indicators of wealth are positively related. In turn, receiving a 20 percent discount voucher increases one's connection probability by close to 15 percentage points. 
In Table 3, we report the first stage estimates described in Equation (3). Clearly, a strong and somewhat constant relationship is found between the number of connected households within a given radius and the number of voucher recipients within that radius. The relationship is robust to the introduction of population density and household-level characteristics as controls. Overall, results from these first stage estimates combined with the random distribution of the vouchers provide strong support to our instrumental variable strategy described in the previous section.

Table 4 displays the results from these instrumental variable estimates. The results are somewhat similar in magnitude to those obtained from the reduced form in Table 2. Here also, while population density and household-level characteristics do contribute to explaining households' connection decisions, they do not affect the main social effect results identified. Accordingly, each additional connected household within a 30 meter radius increases the connection rate by 2.4 percentage points. This relationship vanishes beyond a 100 meter radius, in line with the type of clusters reported in Figure 1.

As pictured in Figure 1, these social interaction effects may help explain the existence of clusters of connected and unconnected households within a given community. Here also, results are in line with results derived elsewhere in the literature. For instance, in their study of 27 villages in Botswana, Ketlogetswe, Mothudi, and Mothibi (2007) found important differences in connection rates across nearby and similar villages, ranging from 2 percent in some villages to 27 percent in others, that cannot be fully explained by village- and household-level characteristics.

\section{Interpretation}

Social interaction effects may result from various types of mechanisms. In particular, and as proposed in Manski (2000), these mechanism may belong to three separate categories. First, constraint interactions are based on the fact that one's behavior may affect (positively or negatively) others' constraints in adopting such behavior. Second, expectation interactions rely on the fact that by observing others' behavior and the corresponding results, one obtains more information regarding the potential benefits of these actions. Such interactions are more often framed as social learning. Finally, preference interactions characterize those situations in which individuals' preferences for a particular set of actions depend on the actions chosen by others for reasons more related to social status, such as attempting to keep up with neighbors' behavior.

Understanding the extent to which such types of mechanisms drive social interaction effects can in turn greatly affect the design of economic policies. For instance, enhancing access to information about the benefits of a given program may affect the existence or magnitude of expectation interactions, but should not affect those social interaction effects driven by preference interactions (see Manski, 2000). While our data does not allow for a direct test of these mechanisms, a range of evidence can be used to assess the plausibility of each mechanism's respective contribution to the effect identified in the previous section.

\subsection{Expectation Interactions}

We first investigate whether the expectation interactions mechanism is a plausible explanation for the social interaction effect we observe. The social learning explanation often appears as the 
default explanation in economic studies. For instance, Devotto et al. (2011) find that neighbors' connection to piped water in urban Morocco has a significant effect on individuals' behavior; they attribute this effect to the fact that households "could have learned from their neighbors about the benefit of being connected". In the context of our study, it could thus be hypothesized that i) people learn from neighbors about the benefits of electricity, ii) they learn from neighbors about the extent of these benefits, or iii) they find out how to get connected to the electrical grid through observing their neighbors. We assess the plausibility of these hypotheses below.

First, and despite the rural locations of the surveyed communities, our data suggests a rather high knowledge of the benefits of electricity at baseline - that is, before any electrical lines were installed in the community. Households were asked to rate their degree of agreement with a number of statements describing the potential advantages and disadvantages of the use of electricity, wood, and kerosene to perform everyday activities. As reported in Column 1 of Table 5 , the overwhelming majority of respondents strongly agreed with most of the advantages of electricity listed in Panel 1, while a much weaker proportion agreed with disadvantages of electricity listed in Panel 2. In comparison, respondents reported little agreement with positive statements regarding the use of kerosene and wood but widely agreed with the disadvantages presented for these fuels. In general, kerosene is perceived as expensive and inappropriate for lighting or cooking, while kerosene fumes are considered toxic. Results for wood show that although it may provide better taste when used for cooking food, wood is scarce, contributes to deforestation, and is relatively expensive when purchased from the market. The majority of respondents also mentioned the important health hazards caused by smoke from wood combustion within the house. Column 2 provides further indications about households' intrinsic valuation of electricity. As reported in Panel 1, electricity is essentially seen as a substitute for kerosene when used for illumination. Accordingly, electricity is thought to provide better lighting and lower health hazards than the former, though Panel 2 also highlights households' fear of potential electrical accidents. In sum, we find that households were rather well informed about the potential advantages and disadvantages of electrification, in contrast with Ranganathan (1993), for whom low connection rates are partly related to households' limited knowledge of electricity. In addition, our results show that electricity is by far the favorite energy source of most households.

As further evidence of the limited explanatory power of social learning in this context, Table 6 presents estimates of the social interaction effect identified previously on the sub-sample of households with the highest perception of electrical benefits at baseline and on the sub-sample of households with a slightly lower, although still high, perception of these benefits. Panel A shows estimates similar to those seen in Panel C of Table 4, in this case applied to the sub-sample of households that responded "strongly agree" to all statements displayed in Panel 1 of Table 5. Lower estimates would have indicated that at least part of the social interaction effect observed is due to the social learning phenomenon, or expectation interpretation. Our results, however, suggest greater estimates for households with the initially highest perception of electricity's benefits. We also find no effect on the sample of less-informed households in Panel B, effectively suggesting that little social learning regarding electricity's benefits affects households' connection decisions. In other words, while learning about the benefits of electricity may have occurred among neighbors, it seems to have had limited consequences on households' decisions regarding whether or not to connect to the electrical grid. 
One may argue, however, that while respondents may have known about electricity's benefits in general, they may have learned the actual extent of those benefits from observing their neighbors. For this to be the case, the magnitude of these benefits must be relatively significant if they are to trigger neighbors' adoption. Yet in the present context, the data suggests rather limited observable benefits, at least in the short time span of the study. As Table 7 reports, we observed low levels of productive electricity use by electrified households. Eighty-seven percent of connected households' installation does not allow for more than four light bulbs; in 95 percent of cases, it allows for fewer than three sockets. In our sample, only one household had an electrical installation capable of powering a refrigerator, a motor, or a water heater. Under such conditions, the productive uses of electricity are restricted to those derived from better lighting within the house. Yet the data also suggests that the majority of households' electrical lighting is used for activities that are not directly productive, such as reading, studying, cooking, etc. Thus, the use of electric lights for productive purposes is only marginal (Table 8). This is not to say that electricity does not affect households' allocation of resources and time in the longer run, but that in the relatively short time span of this study, such effects are unlikely to be observable by peers. $^{4}$

Clearly, the benefits of electricity may also be derived from changes in time allocated to study or leisure activities. To assess the importance of such effects, Table 9 reports estimates of electricity's impact on households' time allocation. For each surveyed household, we collected diary-based measures of the time spent on various activities for up to four individuals, including a male adult, a female adult, and two children. ${ }^{5}$ Column 1 reports simple OLS estimates, while Column 2 relies on Two-Stage Least Square estimates in which the random allocation of vouchers is used as an excluded instrument for a household's decision to connect. Overall, our results indicate no apparent effect of electrification on time allocation over the course of the study. (It should be noted, however, that such effects may well be present in the longer run, so the results presented in Table 9 may reflect the fact that households simply do not adjust immediately to their new electrified status.) The findings in Tables 7-9 suggest that the observable short run benefits of electrification were not significant, thus making it unlikely that households decided to connect based on observations of their neighbors' benefits.

Finally, one may argue that individuals could learn from their neighbors about the steps, price, and procedures necessary to connect to the electrical grid. This argument follows the experimental design of Devotto et al. (2011), who use a door-to-door awareness and facilitation campaign to inform households about the availability of interest-free loan for connection to piped water, as well as application procedure for those loans. In our context, such learning about procedures appears limited. In the surveyed communities, EEPCo (Ethiopia's national power utility) proceeds along the following steps. First, the main electrical line is installed in the village, usually following the main roads. Once the line is installed and ready to operate, the utility sets up a shop in the community that will stay in place for at least a few years. EEPCo then announces in a public meeting that registration is open; at this point, each interested

\footnotetext{
${ }^{4}$ For instance, Dinkleman (2011) finds that rural electrification led to higher participation of women to labor markets in South Africa.

${ }^{5}$ See Juster and Staffor (1991) for a lengthy discussion on appropriate means to collect time allocation data.
} 
household head can indicate, by paying ETB 10, that the household is potentially interested in connecting to the grid. The cost of connection depends in part on the length of the drop-down wire from the nearest pole and the suitability of the house to be electrified. For those households that have registered, EEPCo inspectors estimate the total connection costs that the households will have to pay. Provided that the household can cover these costs, a contract is signed and electricity is installed. Overall, it seems rather clear for any households living in these (small) village communities that becoming connected implies visiting the only electrical utility shop that is permanently based in the village. This is reinforced by the various public announcements made by the electric utility - including announcements made at the time of the public lottery for voucher distribution.

In sum, the available evidence suggests that learning from others about electrification's important benefits, or about the procedures to obtain electrical connection, is unlikely to explain the relatively large social interaction effects identified in the previous section. In other words, while learning from others may have occurred, it is unlikely that it had strong effects on households' decision to connect to the electrical grid over the course of this study.

\subsection{Constraint Interactions}

In the present context, constraint interactions would arise if a household's connection generated positive or negative externalities on others, which may in turn affect those others' connection decisions. This could occur through different avenues. First, a higher demand for connection could affect the connection price. In fact, while the connection price is fixed nationally by the national electric utility, one may argue that nearby households could share fixed connection costs, whereby one house is electrified through EEPCo (the electric utility) and its neighbors later connect to the grid informally-the so-called spiderwebs that are commonly observed in many poor communities. In the present context, however, such features were not observed, in large part because an EEPCo office was permanently installed in each community to provide formal connections and prevent illegal ones. Another price effect could also exist if the price of electrical implements was affected by the level of demand triggered by the number of households connecting to the electrical grid. In our context, however, the only essential implements were light bulbs, which EEPCo made readily available to all connected households.

It could also be argued that a household's connection entails negative externalities on others if, for instance, visitors (friends, relatives, or others) would converge toward electrified houses and no longer visit the non-electrified ones. This could suggest that having more connected neighbors might push households to connect as well in order to not lose acquaintances. However, as we found that electrification has limited effects households' time spent entertaining visitors (see previous section), such effects are unlikely. Finally, it could also be argued that positive externalities exist, whereby one household's connection to electricity also benefits others (for example, by allowing children to go study in the neighbors' electrified house or allowing someone recharge their cell phone using their neighbor's connection). While we cannot rule out such effects, their presence would imply a negative relationship between a household's probability to connect and that household's neighbors' connection status, such that our effects constitute a lower bound on the effective positive influence.

\subsection{Preference Interactions}


Lastly, we turn to what Manski (2000) refers to as preference interactions, whereby the search for conformity or social status contributes to households' decision to connect to the electrical grid in order to either differentiate themselves from their peers or to keep up with their peers. Such a phenomenon has long been documented in the consumption literature, in particular in the late 1940 s in the US when "systems of ascribed social status and social stratification were breaking down or had effectively disappeared" (Mason 2000). ${ }^{6}$ Such social comparisons are also likely to be relevant in developing countries today as traditional norms of consumption and technology-adoption behavior are gradually eroded under the influence of population pressure, market penetration, and access to global media (Platteau, 2006). In fact, some evidence can be found in the rather voluminous literature on relative consumption and subjective well-being, in which keeping up with one's neighbor is a strong determinant of consumption choices (see Fafchamps and Shilpi (2008) or Frey and Stutzer (2002) for a review). Finally, social comparisons may also explain, at least in part, the apparent paradox described in Banerjee and Duflo (2007), whereby otherwise food-limited households in various countries spend a significant amount of (needed) resources on such items as festivals and other visible consumption items.

Rural electrification in African communities may well be subject to this type of effect. For instance, in rural Kenya, Abdullah and Jeanty (2011) found evidence of a sort of class distinction between those who have and those who do not have electricity; in Ghana, Abavana (2000) reported an elevated social status for those who did connect to electricity. Finally, in Zambia, Gustavsson (2002) found that clients of a solar program reported feeling that their life had become more urban-like. Similar anecdotal evidence was reported during fieldwork in the present study, whereby the wire connecting a house to the nearest pole became an important topic of discussion in the village. Finally, one may argue that, given the limited geographical scope of the identified bandwagon effect - about 100 meters - and in the absence of spider-web connections, preference interactions appear as the most plausible explanation for the observed social interaction effects.

\section{Conclusion}

Measurement of social interaction effects can help explain high or low adoption rates of a particular behavior among individuals or households within communities. In turn, understanding the mechanisms underlying these effects can further inform the design of policies meant to prevent or encourage behavior changes. For instance, expectation interactions may call for information campaigns, constraint interactions may require subsidy programs, and preference interactions may suggest the use of tools such as social marketing. It is worth noting that marketing companies are well aware of these different effects and routinely design adapted promotional campaigns to trigger them.

Development programs, however, are yet to develop the kind of tools that take advantage of potentially powerful social interaction effects. One reason for this lies in the limited knowledge

\footnotetext{
${ }^{6}$ E.g. Morgenstern (1948), Duesenberry (1949), Modigliani (1949) or Leibenstein (1950),
} 
of these effects' magnitude and underlying mechanisms, in part related to their difficult empirical identification. In this paper, we use an arguably ideal empirical setting to estimate the size of social interaction effects on households' decision to connect to a rural electrification grid in Ethiopia, combined with an assessment of the most plausible explanation for these effects. Connection rates in rural electrification programs are typically low, despite the potentially important demand found even in poor settings. For instance, studies in various countries have found that the proportion of connected households in grid-electrified villages is as low as 12 percent in Botswana (Ketlogetswe, Mothudi, and Mothibi, 2007), 30 percent in Senegal (ESMAP 2007), and 5 percent in a solar electrification scheme in Kenya (Jacobson, 2007). At the same time, and according to a recent UNICEF study, rural households in Nigeria ranked electricity as their second priority, after safe water but before health centers, roads, education, and fertilizers (ESMAP, 2005).

While our purpose is not to promote policy tools to encourage or discourage households' electrification, our study provides first-hand evidence of the importance of social interaction effects in explaining connection rates. In particular, we show that each additional neighbor connected within a 30 meter radius increases a household's connection probability by about 2 percentage points. Interestingly, our findings are very much in line with Devoto et al. (2011), who find that connection to piped water in urban Morocco is in part determined by neighbors' connections and that these effects decrease with neighbors' distance from one another.

By suggesting that preference interactions are an important part of the explanation, our results carry further policy lessons. For instance, recent debates on so-called smart subsidies propose that consumption subsidies for promoted goods should be specifically targeted to those households that cannot afford the good's face value (see Barnes, D., and J. Halpern (2000) for a discussion related to rural electrification). Yet other evidence suggests that even when important items such as deworming pills are provided for free, take-up remains low in developing countries (Kremer and Miguel, 2007). The existence of preference interactions may call for policies aimed at generating the type of critical mass necessary to trigger social interactions effects.

Since our data does not allow us to perform rigorous empirical tests of this hypothesis, we can only suggest the presence of such preference interaction effects. The potential importance of these effects for policy design therefore calls for rigorous qualitative insights to be collected (as suggested in Manski, 2000) or empirical studies specifically designed for the purpose. To our knowledge, only Banerjee et al. (2011) provide convincing empirical identification of the mechanisms underlying social interaction effects, using detailed social network analysis within a randomized control trial design. Investigating participation rates in a microfinance program in southern India, they find no peer effect over and above that of information transmission, suggesting that expectation interactions dominate in this case. Further research along these lines is warranted. 


\section{References}

Abavana, C. G. 2000. "Renewable Energy for Rural Electrification: The Ghana Initiative." In: ISES, ed Seminaron Rural Energy Provision in Africa. Nairobi, International Solar Energy Society: 77-82.

Abdullah, S., and W. P. Jeanty. 2011. "Willingness to Pay for Renewable Energy: Evidence from a Contingent Valuation Survey in Kenya." Renewable and Sustainable Energy Reviews, 15(6): 2974-2983.

Agyeman, George Aboagye. "Culture as a Catalyst Influencing Consumer Buying Behaviour of Mobile Phone in Koforidua." European Journal of Business and Management 5.7 (2013): 88-95.

Aker, J. C., and I. M. Mbiti. 2010. "Mobile Phones and Economic Development in Africa.” Journal of Economic Perspectives 24 (3): 207-232. 1027.

Akerlof, G. A. 1997. “Social Distance and Social Decision.” Econometrica 65 (5): 1005-

Banerjee, A. V., and E. Duflo. 2007. "The Economic Lives of the Poor." Journal of Economic Perspective 21 (1): 141-167.

Banerjee, A., A. Chandrasekhar, E. Duflo, and M. Jackson. 2011. The Diffusion of Microfinance. MIT Working Paper. Boston: Massachusetts Institute of Technology.

Barnes, D., and J. Halpern. 2000. Subsidies and Sustainable Rural Energy Services: Can We Create Incentives without Distorting Markets? ESMAP Working Paper 10. Washington, DC: Energy Sector Management Assistance Program.

Bernard, T. 2010. "Impact Analysis of Rural Electrification Projects in Sub-Saharan Africa." World Bank Research Observer published online sept 1, 2010.

Bernard, T., and M. Torero. 2011. Randomizing the "Last Mile": A Methodological Note on Using a Voucher-based Approach to Assess the Impact of Infrastructure Projects. IFPRI Discussion Paper 1078. Washington, DC: International Food Policy Research Institute.

Blume, L. E., and S. N. Durlauf. 2005. Identifying Social Interactions: A Review, Mimeo, University of Wisconsin

Brock, W. A., and S. N. Durlauf. 2001. "Interactions-Based Models.” In Handbook of Econometrics. Vol. 5, edited by J. J. Heckman and E. E. Leamer, 3297-3380. North Holland, Amsterdam.

Devoto, F., E. Duflo, P. Dupas, W. Parienté, and V. Pons. 2011. "Happiness on Tap: Piped Water Adoption in Urban Morocco", American Economic Journal: Economic Policy, forthcoming.

Dinkelman, Taryn. "The effects of rural electrification on employment: New evidence from South Africa." The American Economic Review 101.7 (2011): 3078-3108. 
Duesenberry, J. S. 1949. Income, Savings, and the Theory of Consumer Behavior. Cambridge, MA: Harvard University Press.

Duflo, E., and E. Saez. 2003. "The Role of Information and Social Interactions in Retirement Plan Decisions: Evidence from a Randomized Experiment." Quarterly Journal of Economics 118 (3): 815-942.

Dupas, P. 2010. "Short-run subsidies and Long-run Adoption of new health products: evidence from a Field Experiment". NBER Working Paper \#16298.

ESMAP (Energy Sector Management Assistance Program). 2005. Nigeria: Expanding Access to Rural Infrastructures: Issues and Options for Rural Electrification. Washington, DC: World Bank .2007. Maximisation des Retombées de l'Electricité en Zones Rurales, Application au Cas du Sénégal. Washington, DC: World Bank.

Estache, A., and M. Fay. 2007. Current Debates on Infrastructure Policy. Washington, DC: World Bank.

Fafchamps, M., and F. Shilpi. 2008. "Subjective Welfare, Isolation, and Relative Consumption." Journal of Development Economics 86 (1): 43-60.

Frey, B. S., and A. Stutzer. 2002. "What Can Economists Learn from Happiness Research?” Journal of Economic Literature 40: 402-435.

Goldstein, N. J., R. B. Cialdini, and V. Griskevicius. 2008. "A Room with a Viewpoint: Using Social Norms to Motivate Environmental Conservation in Hotels." Journal of Consumer Research 35: 472-482.

Granovetter, M. 1978. "Threshold Models of Collective Behavior." American Journal of Sociology 83 (6): 1420-1443.

Gustavsson, M. 2004. "The Impact of Solar Electric Services on Lifestyle: Experience from Zambia." Journal of Energy in South Africa, 15.

Heltberg, R. 2003. Household Fuel and Energy Use in Developing Countries: A MultiCountry Study. World Bank Oil and Gas Policy Division. Washington, DC: World Bank.

Jacobson, A. 2007. "Connective Power: Solar Electrification and Social Changes in Kenya.” World Development 35 (1): 144-162.

Juster, F.T., and Stafford, F.P. 1991. "The Allocation of Time: Empirical Findings, Behavioral Models, and Problems of Measurement", Journal of Economic Literature, Vol. 29, No. 2 (Jun., 1991), pp. 471-522

Katz, L. F., J. R. Kling, and J. B. Liebman. 2001. "Moving to Opportunity in Boston: Early Results of a Randomized Mobility Experiment." Quarterly Journal of Economics 116: 607-654.

Ketlogetswe, C., T. Mothudi, and J. Mothibi. 2007. "Effectiveness of Botswana's Policy on Rural Electrification.” Energy Policy 35: 1330-1337.

Kremer, M., and E. Miguel. 2007. "The Illusion of Sustainability." Quarterly Journal of Economics 112 (3): 1007-1065. 
Kreutzer, Tino. "Assessing cell phone usage in a South African township school." International Journal of Education \& Development using Information \& Communication Technology 5.5 (2009).

Leibenstein, H. 1950. "Bandwagon, Snob, and Veblen Effects in the Theory of Consumers' Demand." Quarterly Journal of Economics: 183-207.

Manski, C. F. 1993. "Identification of Endogenous Social Effects: The Reflection Problem." Review of Economic Studies 60: 531-542.

. 2000. "Economic Analysis of Social Interactions." Journal of Economic Perspectives 14 (3): 115-136.

Makgosa, R., and K. Mohube. "Peer influence on young adults' products purchase decisions." African Journal of Business Management (2007): 064-071.

Mason, R. 2000. "The Social Significance of Consumption: James Duesenberry's Contribution to Consumer Theory." Journal of Economic Issues 34 (3): 553-572.

Modigliani, F. 1949. "Fluctuations in the Savings-Income Ratio: A Problem in Economic Forecasting." Studies in Income and Wealth 11: 371-343.

Moffitt, R. A. 2001. "Policy Interventions, Low-Level Equilibria, and Social Interactions." In Social Dynamics, edited by S. N. Durlauf and H. Peyton Young, 45-82. Washington, DC: Brookings Institution.

Morgenstern, O. 1948. "Demand Theory Reconsidered." Quarterly Journal of Economics: 165-201.

Platteau, J.-P. 2006. "Solidarity Norms and Institutions in Village Societies: Static and Dynamic Considerations." In Handbook on the Economics of Giving, Reciprocity, and Altruism. Vol. 1, 819-886 Kolm and Ythier eds. North Holland, Amsterdam

Ranganathan, V. 1993. "Rural Electrification Revisited.” Energy Policy, 21(2): 142-151

Sacerdote, B. 2001. "Peer Effects with Random Assignment: Results for Dartmouth Roommates." Quarterly Journal of Economics 116: 681-704.

Scheinkman, J. A. 2008. "Social Interactions." In The New Palgrave Dictionary of Economics, online,.. Palgrave Macmillan.

UNDP (United Nations Development Program). 2006. Human Development Report. New York: United Nations Development Program.

Yang, Jiaqin, Xihao He, and Huei Lee. "Social reference group influence on mobile phone purchasing behaviour: a cross-nation comparative study." International Journal of Mobile Communications 5.3 (2007): 319-338. 
Tables and Figures

Table 1-Experimental integrity

\begin{tabular}{|c|c|c|c|c|}
\hline Mean & $\begin{array}{c}\text { Standard } \\
\text { Deviation }\end{array}$ & Voucher $=0$ & Voucher $=1$ & $\begin{array}{c}\text { Difference: } \\
\text { p-value }\end{array}$ \\
\hline
\end{tabular}

Panel 1. Households' Baseline Characteristics

Consumption expenditures $(* 1,000$ ETB)

Age of household head 41.6

Gender of household head $(1=$ male $) \quad 0.82$

Household size

$5.26 \quad 2.47$

$53.51 \quad 38.40$

$\%$ income from self-employed agriculture

$31.23 \quad 36.69$

$\%$ income from self-employed nonagriculture

$\begin{array}{ll}5.78 & 17.39\end{array}$

$\%$ income from trade activities

14.69

$92.63 \quad 107.89$

Distance to nearest pole $(* 10$ meters $)$

66.09

93.26

199.78

174.73

21.19

315.61

Time for self

33.80

Homework

Entertain visitors

Watch TV/listen to Radio

$4.61 \quad 24.40$

136.19

31.46

47.37

115.23

160.03

130.04

49.40

154.34

106.76

6.11

40.76

0.82

5.14

44.86

31.15

5.19

12.59

94.61

65.00

94.10

213.34

166.70

20.43

307.59

30.75

3.94

128.75

0.77

1.65

2.87

4.56

6.51

8.05

9.28

10.21

11.05

11.64
0.35

0.90

1.77

2.77

3.85

4.96

6.09

7.35

8.59

9.93
6.44

42.17

0.81

5.33

42.65

31.33

6.14

15.94

91.12

66.66

92.82

191.78

178.83

21.57

319.69

35.35

4.95

139.98

0.34

0.98

1.84

2.88

4.12

5.24

6.45

7.53

8.68

9.74
0.32

0.26

0.84

0.39

0.49

0.95

0.51

0.20

0.70

47.20

0.89

0.12

0.27

0.78

0.36

0.33

0.63

0.22

0.88

0.54

0.78

0.78

0.61

0.67

0.63

0.83

0.92

0.84

Note: ETB = Ethiopian birr.

* Time aggregated for up to four respondents per household and divided by the number of respondents 
Figure 1—Households' locations and connection status, example from a southern Ethiopian village

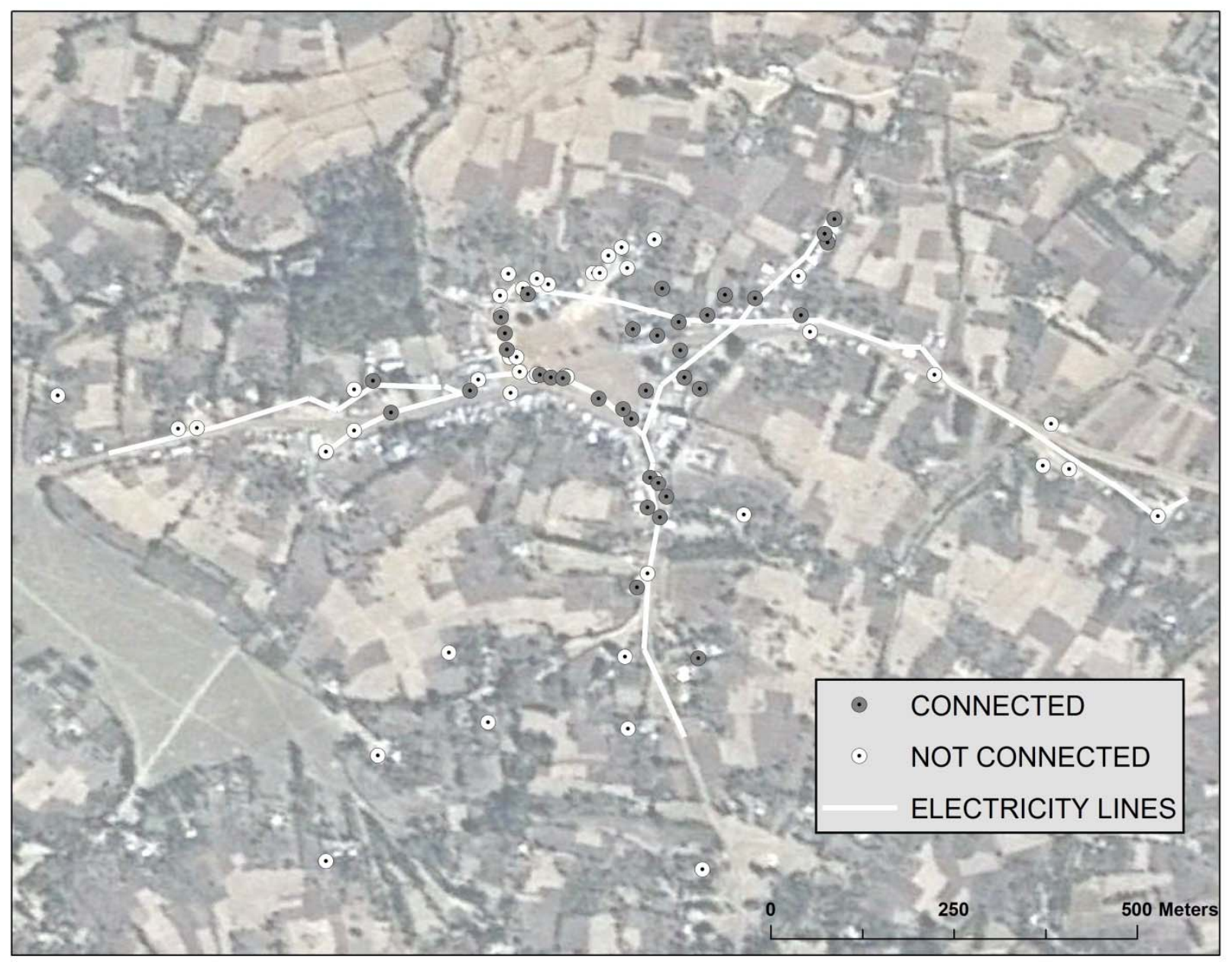


Table 2-Reduced form

\begin{tabular}{|c|c|c|c|c|c|c|c|c|}
\hline Size of radius: & 10-meter & 30-meter & 50-meter & 100-meter & 200-meter & 300-meter & 400-meter & 500-meter \\
\hline $\begin{array}{l}\text { Panel } A \\
\# \text { hh voucher } \\
\text { recipient in radius }\end{array}$ & $\begin{array}{l}0.118 \\
(0.010)^{* * *}\end{array}$ & $\begin{array}{l}0.025 \\
(0.002)^{* * *}\end{array}$ & $\begin{array}{l}0.011 \\
(0.001)^{* * *}\end{array}$ & $\begin{array}{l}0.004 \\
(0.001)^{* * *}\end{array}$ & $\begin{array}{l}0.004 \\
(0.001)^{* *}\end{array}$ & $\begin{array}{r}0.003 \\
(0.002)\end{array}$ & $\begin{array}{r}0.002 \\
(0.003)\end{array}$ & $\begin{array}{r}0.001 \\
(0.003)\end{array}$ \\
\hline $\begin{array}{l}\text { Panel } B \\
\# \text { hh voucher } \\
\text { recipient in radius }\end{array}$ & $\begin{array}{l}0.093 \\
(0.027)^{* *}\end{array}$ & $\begin{array}{l}0.020 \\
(0.004)^{* * *}\end{array}$ & $\begin{array}{l}0.009 \\
(0.002)^{* * *}\end{array}$ & $\begin{array}{l}0.003 \\
(0.001)^{* *}\end{array}$ & $\begin{array}{r}0.002 \\
(0.002)\end{array}$ & $\begin{array}{r}0.001 \\
(0.002)\end{array}$ & $\begin{array}{r}0.003 \\
(0.003)\end{array}$ & $\begin{array}{r}0.002 \\
(0.004)\end{array}$ \\
\hline $\begin{array}{l}\text { Above median } \\
\text { density radius }\end{array}$ & $\begin{array}{r}0.068 \\
(0.054)\end{array}$ & $\begin{array}{r}0.054 \\
(0.043)\end{array}$ & $\begin{array}{l}0.079 \\
(0.033)^{*}\end{array}$ & $\begin{array}{r}0.065 \\
(0.049)\end{array}$ & $\begin{array}{r}0.096 \\
(0.054)\end{array}$ & $\begin{array}{c}0.094 \\
(0.049)^{*}\end{array}$ & $\begin{array}{r}0.063 \\
(0.059)\end{array}$ & $\begin{array}{r}0.070 \\
(0.052)\end{array}$ \\
\hline $\begin{array}{l}\text { Panel } C \\
\# \text { hh voucher } \\
\text { recipient in radius }\end{array}$ & $\begin{array}{l}0.104 \\
(0.026)^{* * *}\end{array}$ & $\begin{array}{l}0.019 \\
(0.004)^{* * *}\end{array}$ & $\begin{array}{l}0.008 \\
(0.002)^{* * *}\end{array}$ & $\begin{array}{l}0.003 \\
(0.001)^{* *}\end{array}$ & $\begin{array}{r}0.002 \\
(0.001)\end{array}$ & $\begin{array}{r}0.001 \\
(0.002)\end{array}$ & $\begin{array}{r}0.003 \\
(0.003)\end{array}$ & $\begin{array}{r}0.002 \\
(0.003)\end{array}$ \\
\hline $\begin{array}{l}\text { Above median } \\
\text { density radius }\end{array}$ & $\begin{array}{r}0.008 \\
(0.055)\end{array}$ & $\begin{array}{r}0.031 \\
(0.043)\end{array}$ & $\begin{array}{l}0.054 \\
(0.026)^{*}\end{array}$ & $\begin{array}{r}0.057 \\
(0.038)\end{array}$ & $\begin{array}{r}0.076 \\
(0.050)\end{array}$ & $\begin{array}{r}0.087 \\
(0.056)\end{array}$ & $\begin{array}{r}0.082 \\
(0.048)\end{array}$ & $\begin{array}{r}0.089 \\
(0.049)\end{array}$ \\
\hline $\begin{array}{l}\text { hh received } 10 \% \\
\text { voucher }\end{array}$ & $\begin{array}{r}0.116 \\
(0.093)\end{array}$ & $\begin{array}{r}0.117 \\
(0.096)\end{array}$ & $\begin{array}{r}0.115 \\
(0.094)\end{array}$ & $\begin{array}{c}0.123 \\
(0.096)\end{array}$ & $\begin{array}{r}0.128 \\
(0.095)\end{array}$ & $\begin{array}{r}0.130 \\
(0.097)\end{array}$ & $\begin{array}{r}0.131 \\
(0.096)\end{array}$ & $\begin{array}{r}0.134 \\
(0.098)\end{array}$ \\
\hline $\begin{array}{l}\text { hh received } 20 \% \\
\text { voucher }\end{array}$ & $\begin{array}{l}0.141 \\
(0.074)^{*}\end{array}$ & $\begin{array}{r}0.135 \\
(0.071)\end{array}$ & $\begin{array}{l}0.138 \\
(0.072)^{*}\end{array}$ & $\begin{array}{c}0.142 \\
(0.075)^{*}\end{array}$ & $\begin{array}{c}0.144 \\
(0.075)^{*}\end{array}$ & $\begin{array}{l}0.144 \\
(0.075)^{*}\end{array}$ & $\begin{array}{l}0.151 \\
(0.072)^{*}\end{array}$ & $\begin{array}{l}0.152 \\
(0.071)^{*}\end{array}$ \\
\hline $\begin{array}{l}\text { Distance to } \\
\text { nearest pole }\end{array}$ & $\begin{array}{l}-0.001 \\
(0.000)^{* *}\end{array}$ & $\begin{array}{l}-0.000 \\
(0.000)^{* *}\end{array}$ & $\begin{array}{l}-0.000 \\
(0.000)^{* *}\end{array}$ & $\begin{array}{l}-0.000 \\
(0.000)^{* *}\end{array}$ & $\begin{array}{l}-0.000 \\
(0.000)^{* *}\end{array}$ & $\begin{array}{l}-0.000 \\
(0.000)^{* *}\end{array}$ & $\begin{array}{l}-0.001 \\
(0.000)^{* * *}\end{array}$ & $\begin{array}{l}-0.001 \\
(0.000)^{* * *}\end{array}$ \\
\hline $\begin{array}{l}\text { Daily consump. } \\
(* 1000)\end{array}$ & $\begin{array}{l}0.022 \\
(0.004)^{* * *}\end{array}$ & $\begin{array}{l}0.022 \\
(0.004)^{* * *}\end{array}$ & $\begin{array}{l}0.022 \\
(0.004)^{* * *}\end{array}$ & $\begin{array}{l}0.022 \\
(0.004)^{* * *}\end{array}$ & $\begin{array}{l}0.022 \\
(0.005)^{* * *}\end{array}$ & $\begin{array}{l}0.022 \\
(0.005)^{* * *}\end{array}$ & $\begin{array}{l}0.021 \\
(0.005)^{* * *}\end{array}$ & $\begin{array}{l}0.020 \\
(0.005)^{* * *}\end{array}$ \\
\hline Age hh head & $\begin{array}{r}0.000 \\
(0.002)\end{array}$ & $\begin{array}{r}0.000 \\
(0.002)\end{array}$ & $\begin{array}{r}0.000 \\
(0.002)\end{array}$ & $\begin{array}{r}0.000 \\
(0.002)\end{array}$ & $\begin{array}{r}0.000 \\
(0.002)\end{array}$ & $\begin{array}{r}0.000 \\
(0.002)\end{array}$ & $\begin{array}{r}0.000 \\
(0.002)\end{array}$ & $\begin{array}{r}0.000 \\
(0.002)\end{array}$ \\
\hline $\mathrm{hh}$ head is male & $\begin{array}{l}0.107 \\
(0.020)^{* * *}\end{array}$ & $\begin{array}{l}0.112 \\
(0.019)^{* * *}\end{array}$ & $\begin{array}{l}0.110 \\
(0.019)^{* * *}\end{array}$ & $\begin{array}{l}0.117 \\
(0.016)^{* * *}\end{array}$ & $\begin{array}{l}0.116 \\
(0.015)^{* * *}\end{array}$ & $\begin{array}{l}0.118 \\
(0.015)^{* * *}\end{array}$ & $\begin{array}{l}0.123 \\
(0.014)^{* * *}\end{array}$ & $\begin{array}{l}0.124 \\
(0.016)^{* * *}\end{array}$ \\
\hline hh size & $\begin{array}{r}0.009 \\
(0.011)\end{array}$ & $\begin{array}{r}0.010 \\
(0.011)\end{array}$ & $\begin{array}{r}0.010 \\
(0.011)\end{array}$ & $\begin{array}{r}0.010 \\
(0.011)\end{array}$ & $\begin{array}{r}0.009 \\
(0.011)\end{array}$ & $\begin{array}{r}0.009 \\
(0.011)\end{array}$ & $\begin{array}{r}0.009 \\
(0.011)\end{array}$ & $\begin{array}{r}0.008 \\
(0.011)\end{array}$ \\
\hline$N$ & 565 & 565 & 565 & 565 & 565 & 565 & 565 & 565 \\
\hline
\end{tabular}

OLS (linear probability) estimate. Dependent variable is whether household has connected to the electrical grid over the course of the study. Robust standard errors clustered at village-level in parentheses. ${ }^{*} p<0.1 ;{ }^{* *} p<0.05 ;{ }^{* * *} p<0.01$. 
Table 3- first stage estimates

\begin{tabular}{|c|c|c|c|c|c|c|c|c|}
\hline Size of radius: & 10 -meter & 30 -meter & 50 -meter & 100 -meter & 200 -meter & 300 -meter & 400 -meter & 500 -meter \\
\hline $\begin{array}{l}\text { Panel } A \\
\# \text { hh voucher } \\
\text { recipient in radius }\end{array}$ & $\begin{array}{l}0.869 \\
(0.040)^{* * *}\end{array}$ & $\begin{array}{l}0.796 \\
(0.008)^{* * *}\end{array}$ & $\begin{array}{l}0.821 \\
(0.003)^{* * *}\end{array}$ & $\begin{array}{l}0.817 \\
(0.007)^{* * *}\end{array}$ & $\begin{array}{l}0.797 \\
(0.055)^{* * *}\end{array}$ & $\begin{array}{l}0.732 \\
(0.138)^{* * *}\end{array}$ & $\begin{array}{l}0.641 \\
(0.223)^{* *}\end{array}$ & $\begin{array}{c}0.565 \\
(0.273)^{*}\end{array}$ \\
\hline $\begin{array}{l}\text { Panel } B \\
\# \text { hh voucher } \\
\text { recipient in radius }\end{array}$ & $\begin{array}{l}0.876 \\
(0.036)^{* * *}\end{array}$ & $\begin{array}{l}0.799 \\
(0.006)^{* * *}\end{array}$ & $\begin{array}{l}0.822 \\
(0.004)^{* * *}\end{array}$ & $\begin{array}{l}0.817 \\
(0.008)^{* * *}\end{array}$ & $\begin{array}{l}0.798 \\
(0.055)^{* * *}\end{array}$ & $\begin{array}{l}0.727 \\
(0.139)^{* * *}\end{array}$ & $\begin{array}{l}0.626 \\
(0.208)^{* *}\end{array}$ & $\begin{array}{l}0.551 \\
(0.248)^{*}\end{array}$ \\
\hline $\begin{array}{l}\text { Above median } \\
\text { density radius }\end{array}$ & $\begin{array}{r}-0.019 \\
(0.018)\end{array}$ & $\begin{array}{r}-0.032 \\
(0.043)\end{array}$ & $\begin{array}{r}-0.036 \\
(0.044)\end{array}$ & $\begin{array}{r}-0.012 \\
(0.076)\end{array}$ & $\begin{array}{r}-0.084 \\
(0.258)\end{array}$ & $\begin{array}{r}0.247 \\
(0.401)\end{array}$ & $\begin{array}{l}-2.384 \\
(1.731)\end{array}$ & $\begin{array}{r}-3.006 \\
(2.063)\end{array}$ \\
\hline $\begin{array}{l}\text { Panel } C \\
\# \text { hh voucher } \\
\text { recipient in radius }\end{array}$ & $\begin{array}{l}0.865 \\
(0.039)^{* * *}\end{array}$ & $\begin{array}{l}0.796 \\
(0.005)^{* * *}\end{array}$ & $\begin{array}{l}0.824 \\
(0.004)^{* * *}\end{array}$ & $\begin{array}{l}0.814 \\
(0.007)^{* * *}\end{array}$ & $\begin{array}{l}0.795 \\
(0.047)^{* * *}\end{array}$ & $\begin{array}{l}0.735 \\
(0.112)^{* * *}\end{array}$ & $\begin{array}{l}0.629 \\
(0.168)^{* * *}\end{array}$ & $\begin{array}{l}0.566 \\
(0.204)^{* *}\end{array}$ \\
\hline $\begin{array}{l}\text { Above median } \\
\text { density radius }\end{array}$ & $\begin{array}{r}-0.020 \\
(0.023)\end{array}$ & $\begin{array}{r}-0.056 \\
(0.059)\end{array}$ & $\begin{array}{r}-0.075 \\
(0.073)\end{array}$ & $\begin{array}{r}-0.071 \\
(0.100)\end{array}$ & $\begin{array}{r}-0.353 \\
(0.360)\end{array}$ & $\begin{array}{r}-0.311 \\
(0.446)\end{array}$ & $\begin{array}{l}-2.514 \\
(1.529)\end{array}$ & $\begin{array}{l}-2.838 \\
(1.701)\end{array}$ \\
\hline $\begin{array}{l}\text { hh received } 10 \% \\
\text { voucher }\end{array}$ & $\begin{array}{r}0.023 \\
(0.036)\end{array}$ & $\begin{array}{r}0.018 \\
(0.030)\end{array}$ & $\begin{array}{r}0.045 \\
(0.028)\end{array}$ & $\begin{array}{r}0.184 \\
(0.128)\end{array}$ & $\begin{array}{r}0.437 \\
(0.343)\end{array}$ & $\begin{array}{r}0.742 \\
(0.549)\end{array}$ & $\begin{array}{r}0.759 \\
(0.549)\end{array}$ & $\begin{array}{r}0.839 \\
(0.586)\end{array}$ \\
\hline $\begin{array}{l}\text { hh received } 20 \% \\
\text { voucher }\end{array}$ & $\begin{array}{r}0.036 \\
(0.034)\end{array}$ & $\begin{array}{r}0.059 \\
(0.037)\end{array}$ & $\begin{array}{r}0.089 \\
(0.060)\end{array}$ & $\begin{array}{r}0.187 \\
(0.136)\end{array}$ & $\begin{array}{r}0.310 \\
(0.229)\end{array}$ & $\begin{array}{r}0.395 \\
(0.265)\end{array}$ & $\begin{array}{r}0.127 \\
(0.159)\end{array}$ & $\begin{array}{r}0.163 \\
(0.211)\end{array}$ \\
\hline $\begin{array}{l}\text { Distance to } \\
\text { nearest pole }\end{array}$ & $\begin{array}{l}-0.000 \\
(0.000)\end{array}$ & $\begin{array}{r}-0.000 \\
(0.000)\end{array}$ & $\begin{array}{r}-0.001 \\
(0.001)\end{array}$ & $\begin{array}{r}-0.002 \\
(0.001)\end{array}$ & $\begin{array}{r}-0.006 \\
(0.004)\end{array}$ & $\begin{array}{l}-0.009 \\
(0.006)\end{array}$ & $\begin{array}{l}-0.013 \\
(0.007)\end{array}$ & $\begin{array}{r}-0.014 \\
(0.008)\end{array}$ \\
\hline $\begin{array}{l}\text { Daily consump. } \\
(* 1000)\end{array}$ & $\begin{array}{l}-0.001 \\
(0.001)\end{array}$ & $\begin{array}{r}-0.007 \\
(0.004)\end{array}$ & $\begin{array}{r}-0.007 \\
(0.006)\end{array}$ & $\begin{array}{r}-0.019 \\
(0.016)\end{array}$ & $\begin{array}{l}-0.066 \\
(0.057)\end{array}$ & $\begin{array}{r}-0.104 \\
(0.085)\end{array}$ & $\begin{array}{l}-0.099 \\
(0.069)\end{array}$ & $\begin{array}{l}-0.115 \\
(0.079)\end{array}$ \\
\hline Age hh head & $\begin{array}{r}-0.000 \\
(0.001)\end{array}$ & $\begin{array}{r}-0.000 \\
(0.001)\end{array}$ & $\begin{array}{c}0.001 \\
(0.001)\end{array}$ & $\begin{array}{c}0.003 \\
(0.003)\end{array}$ & $\begin{array}{c}0.011 \\
(0.010)\end{array}$ & $\begin{array}{r}0.017 \\
(0.014)\end{array}$ & $\begin{array}{r}0.020 \\
(0.013)\end{array}$ & $\begin{array}{r}0.028 \\
(0.017)\end{array}$ \\
\hline $\mathrm{hh}$ head is male & $\begin{array}{r}0.011 \\
(0.013)\end{array}$ & $\begin{array}{r}0.009 \\
(0.012)\end{array}$ & $\begin{array}{r}-0.011 \\
(0.026)\end{array}$ & $\begin{array}{r}0.048 \\
(0.066)\end{array}$ & $\begin{array}{r}0.216 \\
(0.216)\end{array}$ & $\begin{array}{r}0.426 \\
(0.370)\end{array}$ & $\begin{array}{r}0.283 \\
(0.251)\end{array}$ & $\begin{array}{r}0.344 \\
(0.267)\end{array}$ \\
\hline hh size & $\begin{array}{r}-0.003 \\
(0.002)\end{array}$ & $\begin{array}{r}0.003 \\
(0.004)\end{array}$ & $\begin{array}{r}-0.000 \\
(0.011)\end{array}$ & $\begin{array}{r}-0.003 \\
(0.009)\end{array}$ & $\begin{array}{r}-0.066 \\
(0.070)\end{array}$ & $\begin{array}{r}-0.116 \\
(0.117)\end{array}$ & $\begin{array}{r}-0.134 \\
(0.120)\end{array}$ & $\begin{array}{r}-0.113 \\
(0.110)\end{array}$ \\
\hline$N$ & 565 & 565 & 565 & 565 & 565 & 565 & 565 & 565 \\
\hline
\end{tabular}

OLS estimation. Dependent variable is the number of connected neighbors within a given distance radius from one's house. Robust standard errors clustered at village-level in parentheses. ${ }^{*} p<0.1 ; * * p<0.05 ;{ }^{* * *} p<0.01$. 
Table 4 - Instrumental variable estimates

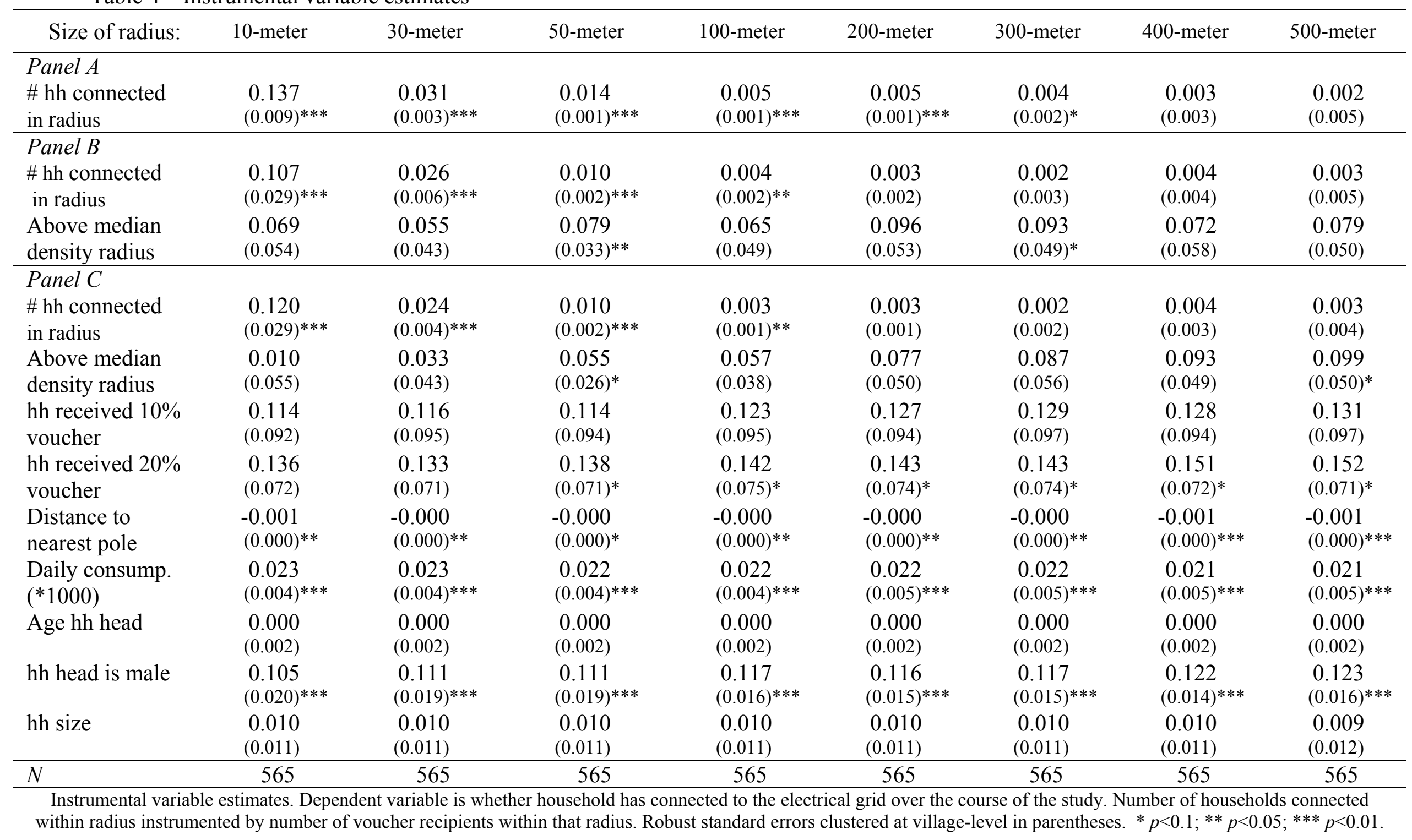


Table 5-Households' perceptions of electricity benefits

\begin{tabular}{lcc}
\hline \hline & $\begin{array}{c}(1) \\
\text { \% strongly } \\
\text { agree* }\end{array}$ & $\begin{array}{c}\text { \% citation as in } \\
\text { main three } \\
\text { benefits** }\end{array}$ \\
\hline Panel 1. Advantages & & \\
Electricity provides better illumination than kerosene oil. & 97.0 & 69.8 \\
Reading is easier with electric lamps than with kerosene lamps. & 97.3 & 22.4 \\
With electricity, children would study more at night. & 93.0 & 30.0 \\
In the electric light, one feels secure at night. & 90.0 & 18.9 \\
Electric lamps do not cause health hazard like kerosene lamps do. & 92.2 & 52.7 \\
Running TV by electricity is less expensive than by battery. & 86.2 & 22.0 \\
It is difficult to work at night without electricity. & 82.2 & 20.8 \\
It is easier to entertain guests in the evening if there is electricity. & 95.3 & 16.9 \\
Electricity is important for our local water supply. & 81.0 & 14.9 \\
Cooking with electricity does not cause smoke. & 89.2 & 13.2 \\
Life would be much easier with electricity. & 87.3 & 8.2 \\
& & \\
Panel 2. Disadvantages & & 61.1 \\
Children would waste their reading time by watching TV. & 26.1 & 84.7 \\
Electricity often causes accidents that may lead one to death. & 54.4 & 39.6 \\
Cooking with electricity is not very convenient. & 9.5 & 45.8 \\
Electricity is very expensive . & 17.1 & 37.1 \\
Accessories (bulbs/meters) are very expensive in electricity. & 18.8 & 23.2 \\
Electricity supply is often irregular and low voltage. & 9.0 & \\
& &
\end{tabular}

\footnotetext{
Notes:

* Response choices varied between "strongly agrees," "tends to agree," "tends to disagree," "strongly disagrees," and "does not know." The percentage of "does not know" answers averages 2.8 percent of the answers and never exceeds 10 percent.

** Within each panel, respondents were asked to identify the three most important advantages that they perceived from electricity from among the proposed statements. That is: respondents were first asked to cite the three main advantages, and later the three main disadvantages. Column 2 reports the percentage of households who reported the item as one of the three main advantages (disadvantages) of electricity.
} 
Table 6-Bandwagon effect on households with higher/lower knowledge of electricity

\begin{tabular}{|c|c|c|c|c|c|c|c|c|}
\hline Radius & $\begin{array}{c}(1) \\
10-\text {-meter }\end{array}$ & $\begin{array}{c}(2) \\
30-\text {-meter }\end{array}$ & $\begin{array}{c}(3) \\
50 \text {-meter }\end{array}$ & $\begin{array}{c}(4) \\
100 \text {-meter }\end{array}$ & $\begin{array}{c}(5) \\
200 \text {-meter }\end{array}$ & $\begin{array}{c}(6) \\
300 \text {-meter }\end{array}$ & $\begin{array}{c}(7) \\
400 \text {-meter }\end{array}$ & $\begin{array}{c}(8) \\
500 \text {-meter }\end{array}$ \\
\hline $\begin{array}{l}\text { Panel } A \text {. Subsamp } \\
\text { \# hh connected in } \\
\text { radius } \\
N\end{array}$ & $\begin{array}{l}\text { ouseholds } \\
0.168 \\
(0.063)^{* *} \\
372\end{array}$ & $\begin{array}{c}\text { ghest knowle } \\
0.049 \\
(0.011)^{* * *} \\
372\end{array}$ & $\begin{array}{l}\text { of electricity } \\
0.021 \\
(0.004)^{* * *} \\
372\end{array}$ & $\begin{array}{l}\text { aseline } \\
\qquad \begin{array}{l}0.009 \\
(0.004)^{* *} \\
372\end{array}\end{array}$ & $\begin{array}{c}0.006 \\
(0.007) \\
372\end{array}$ & $\begin{array}{c}0.004 \\
(0.009) \\
372\end{array}$ & $\begin{array}{c}0.003 \\
(0.013) \\
372\end{array}$ & $\begin{array}{r}0.000 \\
(0.017) \\
372\end{array}$ \\
\hline $\begin{array}{l}\text { Panel B. Subsamp } \\
\text { \# hh connected in } \\
\text { radius }\end{array}$ & $\begin{array}{l}\text { ouseholds } 1 \\
0.058 \\
(0.056)\end{array}$ & $\begin{array}{l}\text { wer knowled } \\
0.009 \\
(0.006)\end{array}$ & $\begin{array}{l}\text { electricity } a \\
0.004 \\
(0.003)\end{array}$ & $\begin{array}{l}\text { seline } \\
0.000 \\
(0.002)\end{array}$ & $\begin{array}{r}0.000 \\
(0.001)\end{array}$ & $\begin{array}{l}-0.000 \\
(0.001)\end{array}$ & $\begin{array}{l}0.005 \\
(0.001)^{* * *}\end{array}$ & $\begin{array}{l}0.005 \\
(0.001)^{* * *}\end{array}$ \\
\hline$N$ & 193 & 193 & 193 & 193 & 193 & 193 & 193 & 193 \\
\hline
\end{tabular}

Robust standard errors clustered at village-level in parentheses. ${ }^{*} p<0.1 ; * * p<0.05 ; * * *<<0.01$.

Reported are second stage of 2SLS estimates. All estimates include the same set of controls as in Panel C of Tables 2, 3 and 4 
Table 7- Electric installation capacities

\begin{tabular}{cccc}
\hline \hline & $\begin{array}{c}\text { \% connected } \\
\text { households with ... } \\
\text { lighting points }\end{array}$ & $\begin{array}{c}\text { \% connected } \\
\text { households with } \\
\text {. } \text { socket outlets }\end{array}$ & $\begin{array}{c}\text { \% connected households } \\
\text { with ... } \\
\text { motor/fridge/heater/stove } \\
\text { socket }\end{array}$ \\
\hline 0 & 0.00 & 49.11 & 99.64 \\
1 & 19.93 & 36.30 & 0.36 \\
2 & 29.54 & 12.10 & 0.00 \\
3 & 22.42 & 2.14 & 0.00 \\
4 & 15.30 & 0.36 & 0.00 \\
$>4$ & 12.81 & 0.00 & 0.00 \\
\hline \hline
\end{tabular}

Table 8- Use of electrical light

\begin{tabular}{llccc}
\hline \multicolumn{1}{c}{ Categories } & 1st usage & $\begin{array}{l}\text { 2nd } \\
\text { usage }\end{array}$ & $\begin{array}{l}\text { 3rd } \\
\text { usage }\end{array}$ \\
\hline $1 \quad$ Reading/studying & 56.52 & 57.42 & 35.72 \\
$2 \begin{array}{l}\text { Other domestic uses (light for eating, } \\
\text { cooking, entertaining friends, and so on) }\end{array}$ & 38.27 & 30.69 & 57.14 \\
3 & $\begin{array}{l}\text { Home business (handicraft, weaving, } \\
\text { sewing, trading, and so on) }\end{array}$ & 5.22 & 11.88 & 7.15 \\
\hline \hline
\end{tabular}


Table 9-Impact of electrification on Time Allocation

OLS coefficients

2SLS coefficients

(Standard errors)

(Standard errors)

(1)

(2)

Dependent variable : Change between Round 2 and Round 1 in per capita time (in mn) allocated to... (cf notes)

Agriculture self-employed

$-6.36$

(9.98)

7.63

20.22

(15.87)

(89.57)

Non-ag self-employed

0.49

58.50

(132.08)

Household chores

(10.76)

$-69.28$

$-0.56$

(98.76)

Child care

$-52.82$

22.11

Time for self

16.63

1.59

(143.97)

Homework

$-71.97$

0.29

Entertain visitors

Watch TV/listen to Radio

2.41

$-1.17$

(11.26)

(92.85)

Notes:

- Total change was aggregated for up to four respondents per household and divided by the number of respondents.

- Each cell reports the estimated coefficient associated to connection at round 2, in a separate estimation including

Consumption/expenditure, Household head's age and gender, household size, sources of income and distance to the nearest pole as additional control variables (coefficients not reported).

- Column (2): connection instrumented by households' voucher status (recipient/non-recipient).

- Robust standard errors in parentheses.

$* p<0.1 ; * * p<0.05 ; * * * p<0.01$ 